\title{
1 Suppression of the in vitro growth and development of Microdochium nivale by phosphite
}

2 J. J. Dempsey*, I. Wilson, P. T. N. Spencer-Phillips and D. Arnold

3 Centre for Research in Biosciences, University of the West of England, Bristol, BS16 1QY

4 *Corresponding author tel.: +353 877673447.Email: John.Dempsey@uwe.ac.uk

$5 \quad$ Running head: Suppression of M. nivale by phosphite

\section{Abstract}

7 The ascomycete fungus Microdochium nivale is a major pathogen of many species of the 8 gramineae. Control measures rely heavily on chemical fungicides, making alternative means 9 of disease reduction desirable. Phosphite $\left(\mathrm{PO}_{3}^{3-,}\right)$ has proven efficacy in reducing susceptibility 10 of different species of gramineae to oomycetes, and has adverse effects on the in vitro growth 11 of numerous other pathogens. The effect of phosphorous acid $\left(\mathrm{H}_{3} \mathrm{PO}_{3}\right)$, phosphoric acid $12\left(\mathrm{H}_{3} \mathrm{PO}_{4}\right)$, dihydrogen potassium phosphite $\left(\mathrm{KH}_{2} \mathrm{PO}_{3}\right)$, dihydrogen potassium phosphate $\left(\mathrm{KH}_{2} \mathrm{PO}_{4}\right)$, and potassium hydroxide $(\mathrm{KOH})$ on the in vitro mycelial growth and development of M. nivale was determined. Radial growth on amended Potato Dextrose Agar (PDA) was used to calculate mean daily growth and percent inhibition. $\mathrm{PO}_{3}{ }^{3-}$ had a significant inhibitory effect on mycelial growth with $\mathrm{EC}_{50}$ values ranging between 35.9 and $40.99 \mu \mathrm{g} / \mathrm{ml}^{-1}$, whilst $\mathrm{PO}_{4}{ }^{3-}$ and $\mathrm{KOH}$ had no significant inhibitory effect. Microscopic examination of mycelia showed morphological deformities in hyphae growing on $\mathrm{PO}_{3}{ }^{3-}$ amended PDA, whilst hyphal growth was normal on $\mathrm{PO}_{4}{ }^{3-}$ and $\mathrm{KOH}$ amended PDA. Conidial germination of M. nivale was significantly reduced following immersion in solutions of 50,100 and $250 \mu \mathrm{g} / \mathrm{ml}$ of $\mathrm{PO}_{3}{ }^{3-}$,

$21 \mathrm{PO}_{4}{ }^{3-}$ and $\mathrm{KOH}$ at same concentrations induced no inhibitory affect. These results show that $\mathrm{PO}_{3}{ }^{3-}$ is a significant inhibitor of the growth of $M$. nivale and may have the potential to be used 23 as a chemical control agent in the field.

24 Keywords: Microdochium nivale, turfgrass, in vitro, phosphite, disease suppression

\section{Introduction}


Microdochium nivale (teleomorph Monographella nivalis (Schafnitt)) is an ascomycete pathogen and causal agent for many disease complexes in numerous graminaceous species (Smiley et al., 1992; Tronsmo et al., 2001). Microdochium nivale produces conidia in large numbers which are readily dispersed by wind and rain splash and, along with soil borne mycelium, are the main source of inoculum (Tronsmo et al., 2001). In turfgrasses, M. nivale is regarded as the most damaging pathogen of temperate climates, infecting and causing disease in most cool season species, causing pink snow mould and microdochium patch (Vargas, 2005). Chemical protectants represent the foremost tool used to control this pathogen (Smiley et al., 1992; Yang et al., 2011) and while the efficacy and safety of these plant protection products is not disputed, development of alternative means of reducing susceptibility is desirable. Phosphite is an attractive alternative to established turfgrass plant protectants for a number of reasons, to date there has been no issues regarding resistance, it is highly mobile within the plant, its ability to induce plant defence responses and its reported enhancement of turfgrass quality. While phosphite is registered as a fungicide in some legislations, in many it is regarded as a biostimulant. However it is the alternative mode of action in suppressing numerous plant pathogens that is of interest here. Phosphite $\left(\mathrm{PO}_{3}{ }^{3-}\right)$ is a reduced form of phosphorus $(\mathrm{P})$ derived from the alkali metal salts of phosphorous acid $\left(\mathrm{H}_{3} \mathrm{PO}_{3}\right)$ (Guest and Grant, 1991). The $\mathrm{pH}$ of phosphorous acid is modified to prevent phytotoxicity, commonly by combining with potassium hydroxide $(\mathrm{KOH})$, forming potassium dihydrogen phosphite $\left(\mathrm{KH}_{2} \mathrm{PO}_{3}\right)$ or dipotassium hydrogen phosphite $\left(\mathrm{K}_{2} \mathrm{HPO}_{3}\right)$. Phosphite is chemically similar to phosphate $\left(\mathrm{PO}_{4}{ }^{3-}\right)$, but the different tetrahedral molecular structure of phosphite ensures that enzymes, which react with phosphate to catalyse metabolic processes, do not bind to phosphite in the same manner ensuring that phosphite does not supply a metabolically usable form of $\mathrm{P}$ (Mcdonald et al., 2001). Phosphite, however, has significant properties as an inhibitor of plant pathogens (Fenn and Coffey, 
51 1984). The mode of suppression remains a subject of debate (Abbasi and Lazarovits, 2006)

with research showing it as acting both directly on the pathogen and indirectly by stimulating host defences (Guest and Grant, 1991).

The use of in vitro studies is an established method to assess a compound's ability either to reduce or inhibit the growth of, or to kill plant pathogenic organisms (Mann, 2002; Glynn et al., 2008; Hofgaard et al., 2010). When compiling a disease protection programme an important factor is determining whether a compound is fungicidal or fungistatic. It is possible that at sufficient concentrations, fungistatic compounds will prevent fungal growth and sporulation fully but, upon removal, the effects are reversed and growth will re-commence. This would have a significant bearing on the application rate and interval.

Most studies on phosphite mediated inhibition of plant pathogens have been on its effects on oomycetes. Suppression of Pythium by phosphite under field conditions was reported by Sanders (1983), but when no in vitro inhibition was demonstrated it was concluded that control resulted from enhanced host defences. However, Fenn and Coffey $(1984,1987)$ demonstrated that phosphite inhibited four Pythium spp. and Phytophthora cinnamomi in vitro. Phytophthora cinnamomi exhibited sensitivity to phosphite with $\mathrm{EC}_{50}$ values (Effective Concentration which reduces growth by $50 \%$ of control growth) ranging from 4 to $148 \mu \mathrm{g} \mathrm{ml}^{-}$ ${ }^{1}$ (Wilkinson et al., 2001). In a later study Pythium spp. were inhibited with $\mathrm{EC}_{50}$ values between 38.7 and $220.8 \mu \mathrm{g} / \mathrm{ml}^{-1}$ (Cook et al., 2009). This direct mode of inhibition seems to involve disruption of the pathogen's metabolism. For example, a study with three Phytophthora species showed that phosphite interfered with phosphate metabolism in pathogen cells by causing an accumulation of polyphosphate and pyrophosphate, diverting ATP from other metabolic pathways, resulting in reduced growth (Niere et al., 1994). Other studies determined that phosphite inhibited enzymes of the glycolytic and phosphogluconate 
pathways, disrupting phosphorus metabolism in $P$. palmivora by competing with phosphate as an allosteric regulator on several enzymes (Stehmann and Grant, 2000).

Less has been published on the in vitro effects of phosphite on fungal pathogens. Reuveni et al. (2003) showed inhibition of Alternaria alternata mycelial growth and conidial germination, while Burpee (2005) reported suppression of in vitro growth of Colletotrichum cereale (Colletotrichum graminicola). Mills et al. (2004) demonstrated that $\mathrm{H}_{2} \mathrm{PO}_{3}$ not only reduced mycelial growth but caused complete inhibition of sporulation of A. alternata, Botrytis cinerea and Fusarium solani. Growth of F. culmorum and F. graminearum was reduced on $\mathrm{KH}_{2} \mathrm{PO}_{3}$ amended PDA (Hofgaard et al., 2010). The same study included the effects of phosphite on Microdochium majus, and found that mycelial growth was reduced by more than $90 \%$ at the lowest $\mathrm{KH}_{2} \mathrm{PO}_{3}$ concentration used $\left(10 \mu \mathrm{g} \mathrm{ml}^{-1}\right)$, with full inhibition at concentrations of $100 \mu \mathrm{g} \mathrm{ml}^{-1}$ (Hofgaard et al., 2010)(Hofgaard et al., 2010)(Hofgaard et al., 2010). However, there has been no published data on the in vitro effect phosphite may have on M. nivale.

Data from turfgrass field trials conducted to evaluate $M$. nivale suppression by $\mathrm{KH}_{2} \mathrm{PO}_{3}$, determined that phosphite significantly $(\mathrm{p}<0.05)$ suppressed disease symptom expression (Dempsey et al., 2012). The success of these trials led to this current research to discover possible modes of suppression. The aims of this research, therefore, were to determine the effect phosphite may have on the in vitro mycelial growth and conidial germination of $M$. nivale, and to determine if phosphite has fungistatic or fungicidal properties.

\section{Materials and methods}

\section{Microdochium nivale mycelial and conidial inoculum}

Four isolates of M. nivale were assessed. Two isolates were obtained from infected Poa annua golf greens on Irish golf courses, the remainder from the Sports Turf Research Institute, Bingley, UK. The isolates were confirmed as M. nivale by Crops Research, Oak Park, Teagasc, 
100 Carlow, using molecular biology techniques as described by Glynn et al. (2005). Conidiation

101 was induced by incubating mycelia in darkness for 48 hours and then exposing to UV light

102 (Jewell and Hsiang, 2013). Conidia were then collected by flooding the plate with sterile

103 distilled water (SDW) and scraping with a sterile rod, immediately before use in experiments.

104 PDA amendments, $\mathrm{H}_{3} \mathrm{PO}_{3}, \mathrm{H}_{3} \mathrm{PO}_{4}, \mathrm{KH}_{2} \mathrm{PO}_{3}, \mathrm{KH}_{2} \mathrm{PO}_{4}$ and $\mathrm{KOH}$

105 Phosphorous acid $\left(\mathrm{H}_{3} \mathrm{PO}_{3}\right)$ and phosphoric acid $\left(\mathrm{H}_{3} \mathrm{PO}_{4}\right)$, were obtained from $1 \mathrm{M}$ reagent 106 grade solutions (supplied by Lennox Laboratory Supplies, Dublin). Dihydrogen potassium

107 phosphite $\left(\mathrm{KH}_{2} \mathrm{PO}_{3}\right)$ and dihydrogen potassium phosphate $\left(\mathrm{KH}_{2} \mathrm{PO}_{4}\right)$ amendments were

108 prepared by titrating $1 \mathrm{M}$ solution phosphorus and phosphoric acids with $6 \mathrm{M}$ reagent-grade

109 potassium hydroxide $(\mathrm{KOH})$ to $\mathrm{pH}$ 6.5. $\mathrm{KOH}$ amendments were prepared from $6 \mathrm{M}$

110 potassium hydroxide, and all amendments were serial diluted to required concentrations.

111 Unamended PDA, containing no additional chemicals, were used as controls. All

112 experimental compounds were filter sterilised and added to autoclaved Potato Dextrose Agar

113 (PDA, 19 g/l, Himedia Potato Dextrose Agar, Sparks Laboratory Supplies, Dublin), after

114 cooling to $50^{\circ} \mathrm{C}$ to ensure no oxidation of phosphite to phosphate (Komorek and Shearer,

115 1997).

116 Measurement of mycelial growth on solid media

117 Experiments were a randomised complete design with six replications. Measurement of

118 mycelial growth of M. nivale isolates, incubated on PDA amended with 0 (unamended

119 control), 10, 50, 100 and $250 \mu \mathrm{g} / \mathrm{ml}$ of $\mathrm{H}_{3} \mathrm{PO}_{3}, \mathrm{H}_{2} \mathrm{PO}_{4}, \mathrm{KH}_{2} \mathrm{PO}_{3}, \mathrm{KH}_{2} \mathrm{PO}_{4}$ and $\mathrm{KOH}$ were used

120 to calculate mean daily growth (MDG), percent relative growth (PRG), percent inhibition and

121 colony diameters. Agar plugs, $5 \mathrm{~mm}$ in diameter, were cut from margins of actively-growing

122 colonies of M. nivale, and transferred to the centre of plates of amended PDA then incubated

123 in darkness in a growth chamber maintained at $18^{\circ}+/-2^{0} \mathrm{C}$. Mycelial growth rate was

124 determined by measuring the colony radius at four points on each plate, from the edge of the 
125 initial inoculum to the extreme outer margin area of fungal mycelial development and growth

126 rates $\left(\mathrm{mm} \mathrm{day}^{-1}\right)$ calculated. Radial growth measurements were taken 1, 2, 3, 4, 5, 6, 7, 8, 9,

127 and 10 days post inoculation (dpi). Mean values of each of the six replicates were used to

128 calculate MDG and PRG on amended compared to unamended control PDA. PRG was

129 calculated as (radial growth on amended PDA/radial growth on unamended control PDA) $\times$

130100 , and was used to calculate percent inhibition (calculated as $100-\mathrm{PRG}=$ percent

131 inhibition). The effective concentrations that reduced mycelial growth by $50 \%\left(\mathrm{EC}_{50}\right)$ and

$13290 \%\left(\mathrm{EC}_{90}\right)$ were determined by probit transforming the PRG and regressing against the

$133 \log _{10}$ of amendment concentrations. This experiment was repeated three times with similar

134 results obtained each time.

\section{Determination of fungistatic properties of phosphite}

136 Experiments were a randomised complete design with six replications. Mycelial plugs,

137 prepared as before, were placed into $10 \mathrm{~mL}$ SDW containing 0 (control), 10, 50, 100 and 250

$138 \mu \mathrm{g} / \mathrm{ml}$ of $\mathrm{H}_{3} \mathrm{PO}_{3}, \mathrm{H}_{2} \mathrm{PO}_{4}, \mathrm{KH}_{2} \mathrm{PO}_{3}, \mathrm{KH}_{2} \mathrm{PO}_{4}$ and $\mathrm{KOH}(\mathrm{n}=6)$, and incubated in darkness in a

139 growth chamber maintained at $18^{\circ}+/-2^{0} \mathrm{C}$ for 10 days. The plugs were retrieved, rinsed twice

140 in SDW and transferred onto fresh unamended PDA and grown in darkness at $18^{\circ}+/-2^{0} \mathrm{C}$

141 (n=6) for 10 dpi. Growth responses were measured and the presence or absence of growth

142 determined if the concentrations were fungicidal or fungistatic. Colony diameters, as

143 determined above on solid media, were also used to assess the fungistacity of phosphite over

$14410 \mathrm{dpi}$. This experiment was repeated twice with similar results each time.

145 Microscopic analysis of the effect of phosphite on hyphal morphology

146 Microdochium nivale hyphal morphology was examined by bright field and fluorescence

147 microscopy using a Bresser epifluorescence microscope. Mycelia, sampled from the outer

148 margins of actively growing colonies, growing on PDA amended with 0 (unamended control),

$14910,50,100$ and $250 \mu \mathrm{g} / \mathrm{ml}$ of $\mathrm{H}_{3} \mathrm{PO}_{3}, \mathrm{H}_{2} \mathrm{PO}_{4}, \mathrm{KH}_{2} \mathrm{PO}_{3}, \mathrm{KH}_{2} \mathrm{PO}_{4}$ and $\mathrm{KOH}$ were examined. The 
150 fluorescent dye, Calcofluor White, was used to visualise hyphae as in Dubas et al. (2010).

151 Images were captured using a Canon D1100 camera and processed by Adobe Photoshop

152 version 5.0 LE (Adobe Systems, Inc., San Jose, CA).

\section{Effects of phosphite on conidial germination}

154 Experiments were a randomised complete design with six replications. Microdochium nivale 155 conidial suspensions were filtered through sterile cheesecloth, to remove mycelium, and $50 \mu 1$ 156 aliquots were transferred to $1.5 \mathrm{ml}$ tubes and mixed with $1 \mathrm{ml}$ solutions of 0 (control), 10, 50, 157100 and $250 \mu \mathrm{g} / \mathrm{ml}$ concentrations of $\mathrm{H}_{3} \mathrm{PO}_{3}, \mathrm{H}_{2} \mathrm{PO}_{4}, \mathrm{KH}_{2} \mathrm{PO}_{3}, \mathrm{KH}_{2} \mathrm{PO}_{4}$ and $\mathrm{KOH}$. Aliquots $158(50 \mu \mathrm{l})$ of the mixtures were pipetted onto depressions in cavity microscope slides and 159 immediately placed on moist tissue paper in $9 \mathrm{~cm}$ Petri dishes and sealed $(\mathrm{n}=6)$. Following 160 incubation in darkness in a growth chamber maintained at $18^{\circ}+/-20 \mathrm{C}$ for $48 \mathrm{~h}$, the samples 161 were agitated using an orbital shaker for $1 \mathrm{~h}$ then $20 \mu \mathrm{l}$ pipetted onto fresh slides. The number 162 of germinating conidia was counted and percent germination calculated (conidia 163 germinated/total conidia $\mathrm{x}$ 100). Conidia were considered to be germinated when the germ

164 tube extended to at least twice the length of the conidium (Mills et al., 2004). This experiment 165 was repeated twice with similar results each time.

\section{Data analysis}

167 Data were analysed using the statistical programme SPSS Statistics 21. Anova assessed for 168 significant differences among the four isolates of $M$. nivale used. Data were assessed prior to 169 analyses to ensure they met the requirements for the relevant statistical methods used. Residual 170 analyses were performed to test for the assumptions of the two-way Anova, outliers assessed 171 by inspection of boxplots, normality assessed using Shapiro-Wilk's normality test and 172 homogeneity of variances was assessed by Levene's test. Two-way Anova, assessed significant

173 effects and interactions on MDG, percent inhibition, the fungicidal or fungistatic properties of 174 phosphite, colony diameters and on the percent germination of conidia. Where there were 
175 significant effects or interactions, one-way Anova, followed by Tukey HSD post hoc tests, at 176 a significance level of $p=0.05$, were used to determine and separate statistical differences. For

177 calculation of $\mathrm{EC}_{50}$ and $\mathrm{EC}_{90}$ values, probit analysis was used to transform percent inhibition

178 from sigmoid to linear data and then regress against the $\log 10$ of amendment concentrations.

179 One-way Anova was then assessed for significant differences among compounds. Where

180 required, data were suitably transformed prior to analyses and back-transformed for 181 presentation of charts.

182 Results

\section{Effects of phosphite on in vitro mycelial growth of $M$. nivale on solid media}

184 Measurement of mycelial growth of M. nivale isolates grown on amended PDA were carried 185 out from 1 to $10 \mathrm{dpi}$. Anova determined no significant $(\mathrm{p}>0.05)$ differences in responses among the four isolates used and therefore the data were pooled to produce mean daily growth rates (MDG). Percent relative growth (PRG) rates of $M$. nivale grown on amended PDA were used to determine the percent inhibition. The analyses determined a significant $(\mathrm{p}<0.05)$ difference in growth inhibition among compounds and rates of concentrations used, (Fig.1).

190 Both $\mathrm{H}_{3} \mathrm{PO}_{3}$ and $\mathrm{KH}_{2} \mathrm{PO}_{3}$ caused significant inhibition of mycelial growth compared to all other compounds. $\mathrm{EC}_{50}$ and $\mathrm{EC}_{90}$ values, calculated at $5 \mathrm{dpi}$, were 40.99 and $80.90 \mu \mathrm{g} / \mathrm{ml}$ for the $\mathrm{H}_{3} \mathrm{PO}_{3}$ and 35.95 and $77.68 \mu \mathrm{g} / \mathrm{ml}$ for the $\mathrm{KH}_{2} \mathrm{PO}_{3}$, respectively. In contrast, there was no

193 significant $(\mathrm{p}>0.05)$ growth inhibition with $\mathrm{H}_{3} \mathrm{PO}_{4}, \mathrm{KH}_{2} \mathrm{PO}_{4}$ and $\mathrm{KOH}$ amendments.

194 Statistical analysis determined the $\mathrm{KH}_{2} \mathrm{PO}_{3}$ PRG growth values were significantly $(\mathrm{p}<0.05)$ lower than the $\mathrm{H}_{3} \mathrm{PO}_{3}$. Mycelial growth of $M$. nivale was suppressed by $\mathrm{PO}_{3}{ }^{3-}$ presence when

196 compared to plates amended with $\mathrm{H}_{3} \mathrm{PO}_{4}, \mathrm{KH}_{2} \mathrm{PO}_{4}$ and $\mathrm{KOH}$ (Fig. 2).

\section{Fungistatic properties of phosphite}

198 Colony diameters of the M. nivale isolates, which had been immersed in a range of compound 
200 diameters with concentrations of 0 (control) and $10 \mu \mathrm{g} / \mathrm{ml}$ had no significant $(\mathrm{p}>0.05$ ) effect.

201 While there were significant $(\mathrm{p}<0.05)$ differences in growth determined following immersion

202 in the $50,100,250$ and $500 \mu \mathrm{g} / \mathrm{ml}$ concentrations, with some suppression of growth, there was

203 no complete inhibition. Further evidence of the fungistatic rather than fungicidal properties of

204 phosphite was determined by measurement of colony diameters growing on $\mathrm{H}_{3} \mathrm{PO}_{3}$ and

$205 \mathrm{KH}_{2} \mathrm{PO}_{3}$ amended PDA at 10 dpi. Evidence that phosphite reduces rather than fully inhibits

206 growth can be seen in Fig 4, which show that colonies continued to grow to the end of the 10

207 dpi experimental period.

\section{Effects of phosphite on hyphal morphology}

209 Microdochium nivale hyphae, viewed using brightfield microscopy at 100x magnification in 210 unamended control PDA (Fig. 5 A) showed normal morphology, as evidenced by the smooth

211 hyphal outlines. Hyphae grown on $\mathrm{H}_{3} \mathrm{PO}_{4}$ (Fig. 5 B) and $\mathrm{KOH}$ (Fig. 5 C) amended PDA, 212 appeared similar to those on unamended controls. M. nivale hyphae grown on $\mathrm{H}_{3} \mathrm{PO}_{3}$ at concentrations of 75 and $100 \mu \mathrm{g} / \mathrm{ml}$ amended PDA, displayed an altered hyphal morphology

214 (Figs 5 D and 5 E). In the presence of phosphite, M. nivale hyphae appeared swollen, short215 branched and stunted, compared to hyphae grown on $\mathrm{PO}_{4}{ }^{3-}$ and $\mathrm{KOH}$ amended plates.

\section{Effects of phosphite on conidial germination}

218 Microdochium nivale conidia in amended solutions were incubated in darkness and conidial

219 germination assessed. Conidia in all the $0 \mu \mathrm{g} / \mathrm{ml}^{-1}$ unamended controls did not achieve $100 \%$

220 germination, with the highest rate of $85.6 \%$ determined in one of the sets of 6 replicates.

221 Whilst there were only minor differences in germination rates in the $10 \mu \mathrm{g} / \mathrm{ml}^{-1}$

222 concentrations of all compounds, at the 50,100 and $250 \mu \mathrm{g} / \mathrm{ml}$ concentrations, germination

223 rates in the $\mathrm{H}_{3} \mathrm{PO}_{3}$ and $\mathrm{KH}_{2} \mathrm{PO}_{3}$ amended plates were significantly $(\mathrm{p}<0.05)$ less than with 224 all other compounds (Fig. 6). 


\section{Discussion}

226 The majority of research with phosphite for controlling plant pathogens has been with oomycetes (Coffey and Bower, 1984; Smillie et al., 1989; Cook et al., 2005; Garbelotto et al., 2008). In contrast, relatively few studies have focused on phosphite suppressing the in vitro growth of ascomycetes (Reuveni et al., 2003; Burpee, 2005). Numerous assessments of $M$. nivale mycelial growth on amended PDA were conducted, and bright field and fluorescence microscopy was used to assess effects on individual hyphae and conidial structures. These studies have shown that phosphite reduces mycelial growth, interferes with morphological development and reduces spore germination. Whilst the effects of phosphite on M. majus were investigated by Hofgaard et al. (2010), the present study is the first to provide equivalent data for $M$. nivale, the more significant pathogen of turf grasses. Significant growth suppression of $M$. nivale was shown in the presence of phosphite with no statistical $(\mathrm{p}>0.05)$ difference between the four $M$. nivale isolates, despite being sourced from different geographical locations. Replication of these studies using a wider pathogen population would be of value as it would verify the findings here that all isolates are affected to similar levels.

240 Phosphite significantly suppressed in vitro mycelial growth of $M$. nivale. This inhibitory

241 effect was also reflected in the disruption of hyphal morphology and the reduction in percent 242 conidial germination. This sensitivity of $M$. nivale to phosphite was further evident from EC50 243 and EC90 values of 40.99 and $80.90 \mu \mathrm{g} / \mathrm{ml}$ for the $\mathrm{H}_{3} \mathrm{PO}_{3}$ and 35.95 and $77.68 \mu \mathrm{g} / \mathrm{ml}$ for the $\mathrm{KH}_{2} \mathrm{PO}_{3}$, respectively, at $5 \mathrm{dpi}$.

While both $\mathrm{H}_{3} \mathrm{PO}_{3}$ and $\mathrm{KH}_{2} \mathrm{PO}_{3}$ inhibited growth, the EC values highlight significant $(\mathrm{p}<0.05)$ differences between these compounds. The differences in EC values could be attributed to combinations of compounds used, where there were significant $(\mathrm{p}<0.05)$ differences between the inhibitory effects of both compounds at all concentrations used, with the exception of the $250 \mu \mathrm{g} / \mathrm{ml}$. Bucking and Heyser (1999) stated that the presence of K facilitates the uptake of 
250 mobile polyphosphate into fungal cells, maintaining that it helps retain the charge balance and $251 \mathrm{pH}$ of the fungal cell and is the counter ion to the transport of polyphosphates into the vacuole.

252 Darakis et al. (1997) concluded the presence of $\mathrm{K}$ facilitated phosphite uptake into 253 Phytophthora capsici hyphae. If mycelial growth suppression is used as an indicator of 254 increased phosphite assimilation, then this enhanced assimilation of phosphite in the presence 255 of $\mathrm{K}$ may have occurred, as statistically $\mathrm{KH}_{2} \mathrm{PO}_{3}$ produced significantly $(\mathrm{p}<0.05)$ greatly inhibition compared to $\mathrm{H}_{3} \mathrm{PO}_{3}$. Compared to phosphite amendments, concentrations of $\mathrm{H}_{3} \mathrm{PO}_{4}$, $\mathrm{KH}_{2} \mathrm{PO}_{4}$ and $\mathrm{KOH}$ induced no similar significant inhibitory effects. The inhibitory effects of phosphate, at concentrations of $50 \mu \mathrm{g} / \mathrm{ml}$ and above, while significantly $(\mathrm{p}<0.05)$ less than that of phosphite, were not unexpected. Reuveni et al. (1996) studying the infection of cucumber (Cucumis sativus L.) by the ascomycete pathogen Sphaerotheca fuliginea (Schlecht.:Fr.), demonstrated that disease symptoms were suppressed by a foliar spray treatment of $\mathrm{KH}_{2} \mathrm{PO}_{4}$. Howard (2001) confirmed that phosphate had fungicidal properties against a number of fungal species in vitro.

264 The effect of $\mathrm{KOH}$ on mycelial growth inhibition is an area of particular interest. Levels of $\mathrm{K}$, currently recommended for management of cool-season amenity turfgrasses, appeared to increase susceptibility to M. nivale, when compared to lower K inputs (Soldat and Koch, 2016). As phosphite is most commonly $\mathrm{pH}$ adjusted with $\mathrm{KOH}$, the results here (Fig. 1) showed that $\mathrm{KOH}$ concentrations of 100 and $250 \mu \mathrm{g} / \mathrm{ml}$ significantly inhibited mycelial growth compared to similar concentrations of $\mathrm{H}_{3} \mathrm{PO}_{4}$ and $\mathrm{KH}_{2} \mathrm{PO}_{4}$. This inhibitory effect possibly due to the increased $\mathrm{pH}$ of $\mathrm{KOH}$ amendments.

271 To date, there have been no published data specifically on the growth suppression of M. nivale,

272 by phosphite in vitro. The results here, however, reflect the findings of Cook et al. (2009), 273 who carried out a series of in vitro studies using $\mathrm{KH}_{2} \mathrm{PO}_{3}$ and $\mathrm{KH}_{2} \mathrm{PO}_{4}$ amended growth 
medium, inoculated with the oomycete pathogen Pythium aphanidermatum. Whilst $\mathrm{KH}_{2} \mathrm{PO}_{3}$ inhibited growth of mycelia, $\mathrm{KH}_{2} \mathrm{PO}_{4}$ had no effect on growth, comparable to the results found here with $M$. nivale suppression. The closest related research to the present study was by Hofgaard et al. (2010), who examined the in vitro mycelial growth of $M$. majus on PDA amended with a range of concentrations of a foliar fertiliser containing $731 \mathrm{~g} / \mathrm{l}$ of a $50 \%$ $\mathrm{KH}_{2} \mathrm{PO}_{3}$ solution. At $10 \mu \mathrm{g} / \mathrm{ml}$, mycelial growth was reduced by more than $90 \%$ and at concentrations above $50 \mu \mathrm{g} / \mathrm{ml}$, growth was inhibited fully. Their results appear to show phosphite as having significantly lower $\mathrm{EC}_{50}$ values than those reported here, either perhaps because $M$. majus is more susceptible to phosphite than $M$. nivale, or possibly due to differences in experimental methods.

The mode of action by which phosphite inhibits mycelial growth has been the subject of a number of studies. Most conclude that inhibition involves disruption of phosphorus metabolism and inhibition of enzymes involved in the glycolytic and phosphogluconate pathways (Grant et al., 1990; Niere et al., 1994; Stehmann, 2000; Mcdonald et al., 2001). Barchietto et al. (1992) demonstrated that phosphite interacts with phosphate for the catalytic site of phosphorylating enzymes, and concluded that in Phytophthora spp. the activity of phosphite produced a physiological state similar to that produced as a result of $\mathrm{P}$ limitation.

291 The disruption to hyphal morphology in M. nivale may be due to $\mathrm{P}$ deficiency in the presence of phosphite. This malformation of hyphae induced by phosphite/phosphate antagonism was also seen by Wong (2006), who studied the effect of phosphite on the hyphal morphology of

294 Phytophthora spp. In the presence of phosphite, hyphae were stunted and swollen, again in a manner similar to those of $M$. nivale. This $\mathrm{P}$ deficiency view is supported by the findings of Niere et al. (1994), who concluded that phosphite inhibition in Phytophthora spp. was due to interference with phosphate metabolism, as the presence of phosphite led to increases in both 
298 pyrophosphate and polyphosphate. They concluded that increased accumulation of phosphite interfered with phosphate metabolism and diverted ATP from other pathways of metabolism, resulting in decreased mycelial growth rates. Furthermore, they suggest that accumulation of pyrophosphate and polyphosphate also alters the ion balance concentrations of potassium, magnesium, calcium and iron, influencing the activity of enzymes catalysing essential steps

303 in metabolism.

304 An important aspect of this study was to determine if phosphite acted as a fungicide and killed the pathogen or was fungistatic, reducing or slowing hyphal growth. Evidence of the fungistatic properties of phosphite were clearly demonstrated when, after being immersed in a range of phosphite concentrations for 10 days, $M$. nivale recommenced growth after transfer to un-amended PDA, without displaying any major malformation and in a manner similar to the samples immersed in phosphate and $\mathrm{KOH}$. Complimenting these data, and supporting the fungistatic rather than fungicidal properties of phosphite, are that when plated on phosphite

311 amended PDA, $M$. nivale growth, while significantly reduced, was not fully suppressed, but 312 continued to grow at a reduced rate over $10 \mathrm{dpi}$.

313 The ability of oomycetes and fungi to tolerate the presence of phosphite and maintain a suppressed growth rate can be explained by Dunstan et al. (1990), who found that $P$. palmivora was able to remove phosphite from its mycelium. Similarly, Smillie et al. (1989) found that phosphite accumulated in $P$. palmivora during the first 5 days of growth, but showed a 317 subsequent decrease in cellular phosphite. Results of a metabolite profile study of 318 Phytophthora spp. by Grant et al. (1990) led them to conclude that phosphite accumulation in 319 mycelium was transient, as within 9 days phosphite had completely disappeared from the mycelium. This supports the findings in this present study, were we found full suppression of growth 5 dpi in PDA amended with phosphite at $250 \mu \mathrm{g} / \mathrm{ml}$. However, from 6 to 10 dpi growth in the $250 \mu \mathrm{g} / \mathrm{ml}$ amendments commenced and increased toward the end of the 10 dpi period. 
323 This area merits further research as to the means by which this occurs. It may be that as

324 phosphite is assimilated by the fungus phosphite to phosphate ratio in the media is altered and as Smillie et al. (1989) concluded phosphate significantly influences the take up of phosphite This determination of phosphite as a fungistat rather than a fungicide has significant relevance to disease control programmes and to the marketing of phosphite products. Depending on the active ingredient and its biochemical mode of action, a fungicide can be applied either as a preventative measure or as a curative to control disease infection. With a fungistatic compound, which slows the growth rather than kills the pathogen, the control programme usually requires treatment as a preventative measure, therefore requiring continuous sequential applications. The sequential application programme would ensure the phosphite was always present in planta, in order to continually suppress pathogen growth.

334 Conidial production is vital in the spread of inoculum, therefore any reduction would have a significant impact on disease spread and incidence. The results here show that the inclusion of phosphite in the propagating solution led to a significant reduction in conidial germination. This inhibition of spore germination by phosphite has been well documented in oomycetes,

338 but less so in ascomycetes (Reuveni et al., 2003; Mills et al., 2004). Wong (2006) for example, showed that phosphite retarded spore germination in Phytophthora spp., and also provided evidence that phosphite caused distortion and lysis of the spores. Although

341 phosphite inhibited spore germination in $M$. nivale, no conidial distortion or lysis was 342 observed. While there are no published data on the effect phosphite has on M. nivale conidial 343 germination, Hofgaard et al. (2010) demonstrated that increased phosphite concentrations correlated directly with delayed sporulation of M. majus on detached wheat leaves. Based on in vitro and detached leaf experiments, they concluded phosphite can suppress fungal 346 reproduction and slow pathogenic growth, allowing a host plant's defence system time to 347 react, reducing the severity of infection. 
348 This study has produced significant and novel data which is relevant to methods of turfgrass

349 disease prevention and control. The main conclusions are that phosphite suppressed M. nivale

350 mycelial growth, disrupted hyphal morphology and reduced conidial germination. Both hyphae

351 and conidia are infective propagules, providing inoculum for the diseases caused by M. nivale.

352 It is clearly demonstrated here that the incorporation of phosphite into growth media

353 significantly suppresses the growth and development of these infective propagules in vitro and

354 therefore supports the findings of Dempsey et al. (2012) where it was demonstrated that

355 phosphite significantly reduced $M$. nivale infection in the field. Further work in this area should

356 assess the possible effect on turfgrass phosphate metabolism in the presence of phosphite and

357 determine any effects on turfgrass growth.

\section{$358 \quad$ References}

Abbasi, P. A. and Lazarovits, G. (2006). Seed treatment with phosphonate (AG3) suppresses pythium dampingoff of cucumber seedlings. Plant Disease 90(4): 459-464.

Barchietto, T., Saindrenan, P. and Bompeix, G. (1992). Physiological responses of Phytophthora citrophthora to a subinhibitory concentration of phosphonate. Pesticide Biochemistry and Physiology 42(2): 151-166.

Bücking, H. and Heyser, W. (1999). Elemental composition and function of polyphosphates in ectomycorrhizal fungi - an X-ray microanalytical study. Mycological Research 103(1): 31-39.

Burpee, L. L. (2005). Sensitivity of Colletotrichium graminicola to phosphonate fungicides. International Turfgrass Society Research Journal 10: 163-169.

Coffey, M. D. and Bower, L. A. (1984). In vitro variability among isolates of eight Phytophthora species in response to phosphorous acid. Phytopathology 74: 738-742.

Cook, J., Landschoot, P. J. and Schlossberg, M. J. (2005). Evaluation of phosphonate fungicides for control of anthracnose basal rot and putting green quality: 1-14.

Cook, P. J., Landschoot, P. J. and Schlossberg, M. J. (2009). Inhibition of Pythium spp. and suppression of pythium blight of turfgrasses with phosphonate Fungicides. Plant Disease 93(8): 809-814.

Darakis, G. A., Bourbos, V. A. and Skoudridakis, M. T. (1997). Phosphonate transport in Phytophthora capsici. Plant Pathology 46(5): 762-772.

Dempsey, J. J., Wilson, I. D., Spencer-Phillips, P. T. N., et al. (2012). Suppression of Microdochium nivale by potassium phosphite in cool-season turfgrasses. Acta Agriculturae Scandinavica, Section B - Plant Soil Science 62(Supplement 1): 70-78.

378 Dubas, E., Golebiowska, G., Zur, I., et al. (2010). Microdochium nivale (Fr., Samuels \& Hallett): cytological

Dunstan, R. H., Smillie, R. H. and Grant, B. R. (1990). The effects of sub-toxic levels of phosphonate on the metabolism and potential virulence factors of Phytophthora palmivora. Physiological and Molecular Plant Pathology 36(3): 205-220.

Fenn, M. and Coffey, M. D. (1987). Phosphonate Fungicides for control of diseases caused by Phytophthora. California Avocado Society 1987 Yearbook 71: 241-249.

Fenn, M. E. and Coffey, M. D. (1984). Studies on the in vitro and in vivo antifungal activity of Fosetyl-Al and phosphorus acid. Phytopathology 74(5): 606-611.

Garbelotto, M., Harnik, T. Y. and Schmidt, D. J. (2008). Efficacy of phosphonic acid, metalaxyl-M and copper hydroxide against Phytophthora ramorum in vitro and in planta. Plant Pathology 58(1): 1-9.

Glynn, N. (2005). Phylogenetic analysis of EF-1 alpha gene sequences from isolates of Microdochium nivale

390 leads to elevation of varieties majus and nivale to species status. Mycological Research 109(8): 872-880. 
Glynn, N. C., Hare, M. C. and Edwards, S. G. (2008). Fungicide seed treatment efficacy against Microdochium nivale and M. majus in vitro and in vivo. Pest Management Science 64(8): 793-799.

Guest, D. and Grant, B. (1991). The complex action of phosphonates as antifungal agents. Biological Reviews 66(2): 159-187.

Hofgaard, I. S., Ergon, A., Henriksen, B., et al. (2010). The effect of potential resistance inducers on development of Microdochium majus and Fusarium culmorum in winter wheat. European Journal of Plant Pathology 128(2): 269-281.

Howard, K. (2001). The effect of the fungicide phosphite on ectomycorrhizal fungi. Scool of Biological Sciences and Biotechnology, Murdoch.

Jewell, L. and Hsiang, T. (2013). Differences in the timing and mechanisms of the infection processes of Microdochium nivale and Microdochium majus on wheat (Triticum aestivum) and Kentucky bluegrass (Poa pretensis). International Turfgrass Society Research Journal 12: 111-118.

Komorek, B. M. and Shearer, B. L., Eds. (1997). Application technologies and phosphonate movement in the host. Control of Phytophthora and Diplodina canker in Western Australia.

Mann, R. (2002). In vitro fungicide sensitivity of Microdochium nivale isolates from the UK. Journal of Turfgrass and Sports Surface Science 78(25-30).

McDonald, A., Grant, B. and Plaxton, W. (2001). Phosphite (phosphorous acid): its relevance in the environment and agriculture and influence on plant phosphate starvation response. Journal of Plant Nutrition 24(10): 1505-1519.

Mills, A. A. S., Platt, H. W. and Hurta, R. A. R. (2004). Effect of salt compounds on mycelial growth, sporulation and spore germination of various potato pathogens. Postharvest Biology and Technology 34(3): 341350 .

Niere, J., Deangelis, G. and Grant, B. (1994). The effect of phosphonate on the acid-soluble phosphorus components in the genus Phytophthora. Microbiology 140(7): 1661-1670.

Reuveni, M., Agapov, V. and Reuveni, R. (1996). Controlling powdery mildew caused by Sphaerotheca fuliginea in cucumber by foliar sprays of phosphate and potassium salts. Crop Protection 15: 49-53.

Reuveni, M., Sheglov, D. and Cohen, Y. (2003). Control of moldy-core decay in apple fruits by $\beta$-Aminobutyric acids and potassium phosphites. Plant Disease 87(8): 933-936.

Sanders, P. L. (1983). Control of Pythium spp. and pythium blight of turfgrass with Fosetyl Aluminum. Plant Disease 67(12): 1382-1383.

Smiley, R., Dernoeden, P. and Clarke, B. (1992). Compendium of Turfgrass Diseases.2nd Ed St Paul, APS Press.

Smillie, R., B. R. Grant and Guest, D. (1989). The mode of action of phosphite: evidence for both direct and indirect modes of action on three Phytophthora spp. in plants. Phytopathology 79(9): 921-926.

Soldat, D. and Koch, P. (2016) Potassium fertilization increases microdochium patch incidence and severity on creeping bentgrass. Crop Science Society of America, Phoenix, Arizona.

Stehmann, C. (2000). Inhibition of enzymes of the glycolytic pathway and hexose monophosphate bypass by phosphonate. Pesticide Biochemistry and Physiology 67(1): 13-24.

Tronsmo, A. M., Hsiang, T., Okuyama, H., et al. (2001). Low temperature diseases caused by Microdochium nivale. Low temperature plant microbe interactions under snow. D. A. G. N. Iriki, A.M. Tronsmo, N. Matsumoto, M. Yoshida and a. A. Nishimune. Sapporo, Japan., Hokkaido National Agricultural Experiment Station.

Vargas, J. (2005). Management of Turfgrass Diseases New Jersey, Wiley and Sons.

Wilkinson, C. J., Shearer, B. L., Jackson, T. J., et al. (2001). Variation in sensitivity of Western Australian isolates of Phytophthora cinnamomi to phosphite in vitro. Plant Pathology 50(1): 83-89.

Wong, M.-H. (2006). Phosphite induces morphological and molecular changes in Phytophthora. School of Biological Sciences and Biotechnology. Perth, Australia, Murdoch

Yang, C., Hamel, C., Vujanovic, V., et al. (2011). Fungicide: modes of action and possible impact on nontarget microorganisms. ISRN Ecology 2011: 1-8.

\section{Figure legends}

Figure 1 Inhibition of Microdochium nivale mycelial growth on phosphorous acid $\left(\mathrm{H}_{3} \mathrm{PO}_{3}\right)$, phosphoric acid $\left(\mathrm{H}_{3} \mathrm{PO}_{4}\right)$, dihydrogen potassium phosphite $\left(\mathrm{KH}_{2} \mathrm{PO}_{3}\right)$, dihydrogen potassium phosphate $\left(\mathrm{KH}_{2} \mathrm{PO}_{4}\right)$, and potassium hydroxide (KOH) amended PDA. 
Inhibition of $M$. nivale mycelial growth on PDA amended with a: $10 \mu \mathrm{g} / \mathrm{ml} ; \mathrm{b}: 50 \mu \mathrm{g} / \mathrm{ml} ; \mathrm{c}: 100 \mu \mathrm{g} / \mathrm{ml}$; d: 250 $\mu \mathrm{g} / \mathrm{ml}$ of $\mathrm{H}_{3} \mathrm{PO}_{3}, \mathrm{H}_{2} \mathrm{PO}_{4}, \mathrm{KH}_{2} \mathrm{PO}_{3}, \mathrm{KH}_{2} \mathrm{PO}_{4}$ and $\mathrm{KOH}$, presented as $\%$ inhibition of growth on unamended PDA. Growth rates calculated from pooled data of each of the four $M$. nivale isolates, $\mathrm{n}=6$, by measuring the colony radii at four points on each plate, 4 dpi. Bars are 95\% confidence intervals. Letters indicate significant differences among compounds, as determined by Tukey HSD at $\mathrm{p}=0.05$.

Figure 2 Microdochium nivale colonies on amended PDA at 5 days post inoculation.

A: unamended control; B: phosphorous acid $\left(\mathrm{H}_{3} \mathrm{PO}_{3}\right), 100 \mu \mathrm{g} / \mathrm{ml}$; C: phosphoric acid $\left(\mathrm{H}_{3} \mathrm{PO}_{4}\right), 100 \mu \mathrm{g} / \mathrm{ml}$; D: dihydrogen potassium phosphite $\left(\mathrm{KH}_{2} \mathrm{PO}_{3}\right), 100 \mu \mathrm{g} / \mathrm{ml}$; E: dihydrogen potassium phosphate $\left(\mathrm{KH}_{2} \mathrm{PO}_{4}\right), 100$ $\mu \mathrm{g} / \mathrm{ml} \mathrm{F}$ : potassium hydroxide (KOH), $100 \mu \mathrm{g} / \mathrm{ml}$.

Figure 3 Effect of immersion of Microdochium nivale mycelium in solutions of phosphorous acid $\left(\mathrm{H}_{3} \mathrm{PO}_{3}\right)$, phosphoric acid $\left(\mathrm{H}_{3} \mathrm{PO}_{4}\right)$, dihydrogen potassium phosphite $\left(\mathrm{KH}_{2} \mathrm{PO}_{3}\right)$, dihydrogen potassium phosphate $\left(\mathrm{KH}_{2} \mathrm{PO}_{4}\right)$, and potassium hydroxide $(\mathrm{KOH})$.

Microdochium nivale colony diameters $(\mathrm{mm}) 5$ days after transfer to unamended PDA, following immersion for 10 days in a: $50 \mu \mathrm{g} / \mathrm{ml}$; b: $100 \mu \mathrm{g} / \mathrm{ml}$; c: $250 \mu \mathrm{g} / \mathrm{ml}$; d: $500 \mu \mathrm{g} / \mathrm{ml}$ solutions of $\mathrm{H}_{3} \mathrm{PO}_{3}, \mathrm{H}_{2} \mathrm{PO}_{4}, \mathrm{KH}_{2} \mathrm{PO}_{3}, \mathrm{KH}_{2} \mathrm{PO}_{4}$ and $\mathrm{KOH}$. Data are mean values, $\mathrm{n}=6$, pooled from four M. nivale isolates. Bars are $95 \%$ confidence intervals. Letters indicate significant differences between colony diameters at each compound concentration used, as determined by Tukey HSD at $\mathrm{p}=0.05$.

Figure 4 Radial growth of Microdochium nivale mycelium 10 days post inoculation on phosphorous acid $\left(\mathrm{H}_{3} \mathrm{PO}_{3}\right)$ and dihydrogen potassium phosphite $\left(\mathrm{KH}_{2} \mathrm{PO}_{3}\right)$ amended PDA.

469

Microdochium nivale colony diameters in $\mathrm{mm}, 10$ days post inoculation, growing on PDA amended with 0 (control), 10, 50100 and $250 \mu \mathrm{g} / \mathrm{ml}$ of $\mathrm{H}_{3} \mathrm{PO}_{3}$ and $\mathrm{KH}_{2} \mathrm{PO}_{3}$. Colony diameters were determined by measuring the radii at four points on each plate. Bars are $95 \%$ confidence intervals. Letters indicate significant differences between compounds at each amendment concentration, as determined by Tukey HSD at $\mathrm{p}=0.05$.

Figure 5 Brightfield micrographs of Microdochium nivale hyphal growth in amended PDA. phosphorous acid $\left(\mathrm{H}_{3} \mathrm{PO}_{3}\right), 75 \mu \mathrm{g} / \mathrm{ml}$; e: phosphorous acid $\left(\mathrm{H}_{3} \mathrm{PO}_{3}\right), 100 \mu \mathrm{g} / \mathrm{ml}$.

Figure 6 Effect of phosphite on germination of Microdochium nivale conidia.

Germination of M. nivale conidia following immersion in solutions of a: $10 \mu \mathrm{g} / \mathrm{ml} ; \mathrm{b}: 50 \mu \mathrm{g} / \mathrm{ml} ; \mathrm{c}: 100 \mu \mathrm{g} / \mathrm{ml}$; d: $250 \mu \mathrm{g} / \mathrm{ml} \mu \mathrm{g} / \mathrm{ml}$ concentrations of phosphorous acid $\left(\mathrm{H}_{3} \mathrm{PO}_{3}\right)$, phosphoric acid $\left(\mathrm{H}_{3} \mathrm{PO}_{4}\right)$, dihydrogen potassium phosphite $\left(\mathrm{KH}_{2} \mathrm{PO}_{3}\right)$, dihydrogen potassium phosphate $\left(\mathrm{KH}_{2} \mathrm{PO}_{4}\right)$, and potassium hydroxide $(\mathrm{KOH})$ after incubation at $18^{\circ}+/-2^{0} \mathrm{C}$ for $48 \mathrm{~h}$. Data were arcsine transformed prior to analysis and back-transformed for this graph. Bars are $95 \%$ confidence intervals. Letters indicate significant differences between compounds as determined by Tukey HSD at $\mathrm{p}=0.05$. 


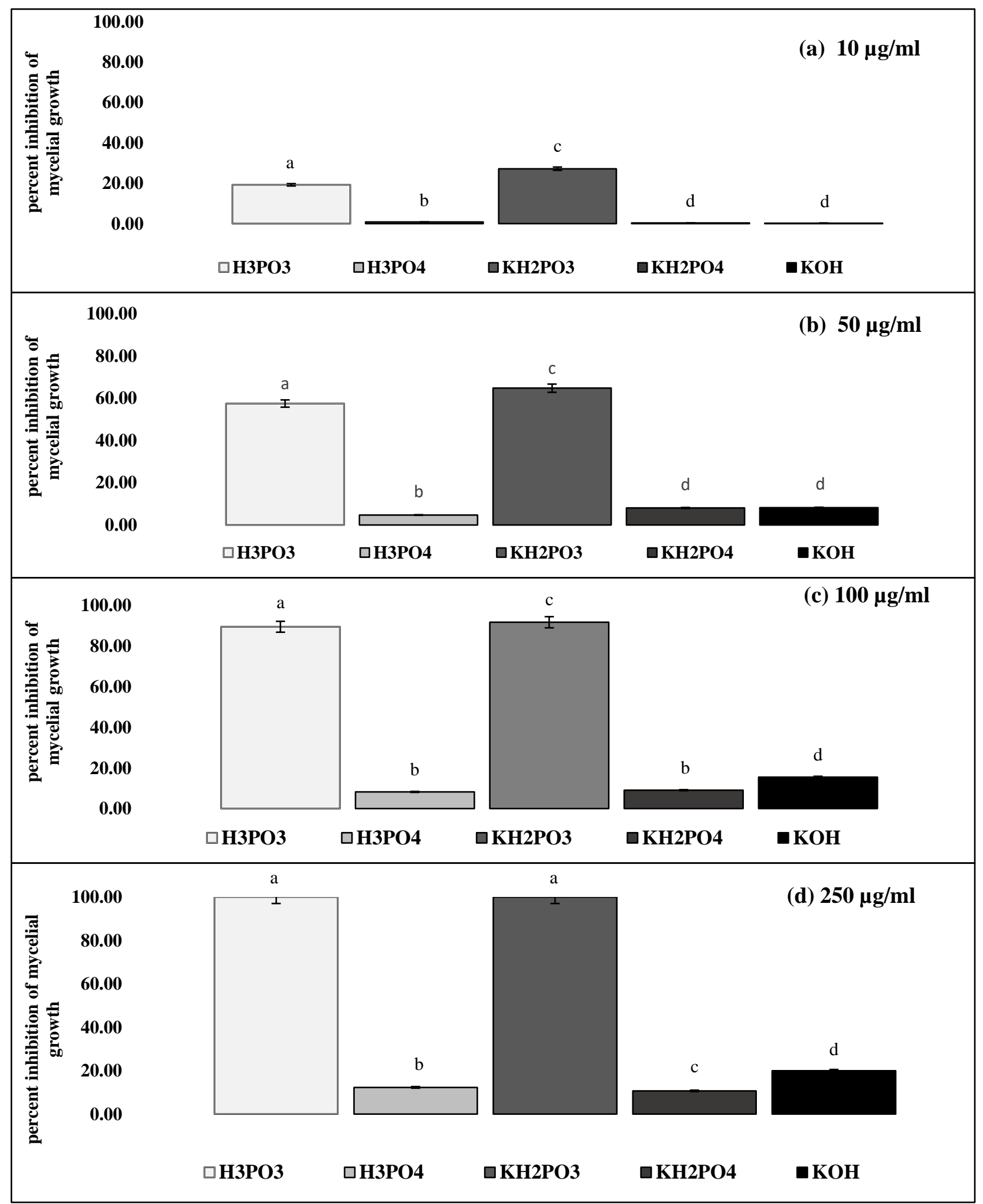

Figure 1 Inhibition of Microdochium nivale mycelial growth on phosphorous acid $\left(\mathrm{H}_{3} \mathrm{PO}_{3}\right)$, phosphoric acid $\left(\mathrm{H}_{3} \mathrm{PO}_{4}\right)$, dihydrogen potassium phosphite $\left(\mathrm{KH}_{2} \mathrm{PO}_{3}\right)$, dihydrogen potassium phosphate $\left(\mathrm{KH}_{2} \mathrm{PO}_{4}\right)$, and potassium hydroxide $(\mathrm{KOH})$ amended PDA.

Inhibition of $M$. nivale mycelial growth on PDA amended with a: $10 \mu \mathrm{g} / \mathrm{ml} ; \mathrm{b}: 50 \mu \mathrm{g} / \mathrm{ml} ; \mathrm{c}: 100 \mu \mathrm{g} / \mathrm{ml}$; d: $250 \mu \mathrm{g} / \mathrm{ml}$ of $\mathrm{H}_{3} \mathrm{PO}_{3}, \mathrm{H}_{2} \mathrm{PO}_{4}, \mathrm{KH}_{2} \mathrm{PO}_{3}, \mathrm{KH}_{2} \mathrm{PO}_{4}$ and $\mathrm{KOH}$, presented as $\%$ inhibition of growth on unamended PDA. Growth rates calculated from pooled data of each of the four $M$. nivale isolates, $\mathrm{n}=6$, by measuring the colony radii at four points on each plate, 4 dpi. Bars are $95 \%$ confidence intervals. Letters indicate significant differences among compounds, as determined by Tukey HSD at $\mathrm{p}=0.05$. 


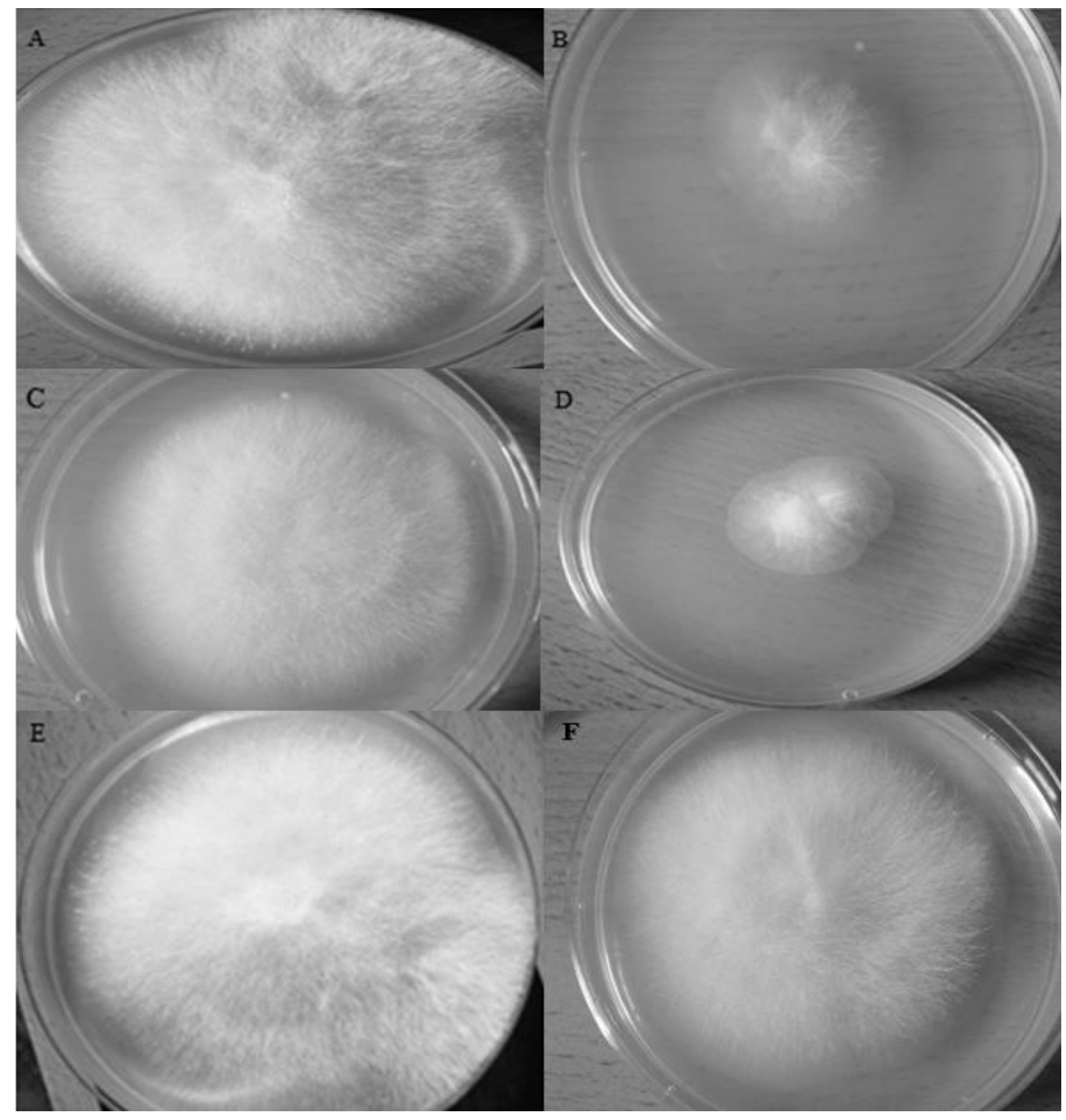

Figure 2 Microdochium nivale colonies on amended PDA at 5 days post inoculation.

A: unamended control; B: phosphorous acid $\left(\mathrm{H}_{3} \mathrm{PO}_{3}\right), 100 \mu \mathrm{g} / \mathrm{ml}$; C: phosphoric acid $\left(\mathrm{H}_{3} \mathrm{PO}_{4}\right), 100 \mu \mathrm{g} / \mathrm{ml} ; \mathrm{D}$ : dihydrogen potassium phosphite $\left(\mathrm{KH}_{2} \mathrm{PO}_{3}\right), 100 \mu \mathrm{g} / \mathrm{ml}$; E: dihydrogen potassium phosphate $\left(\mathrm{KH}_{2} \mathrm{PO}_{4}\right), 100$ $\mu \mathrm{g} / \mathrm{ml} \mathrm{F}$ : potassium hydroxide $(\mathrm{KOH}), 100 \mu \mathrm{g} / \mathrm{ml}$. 


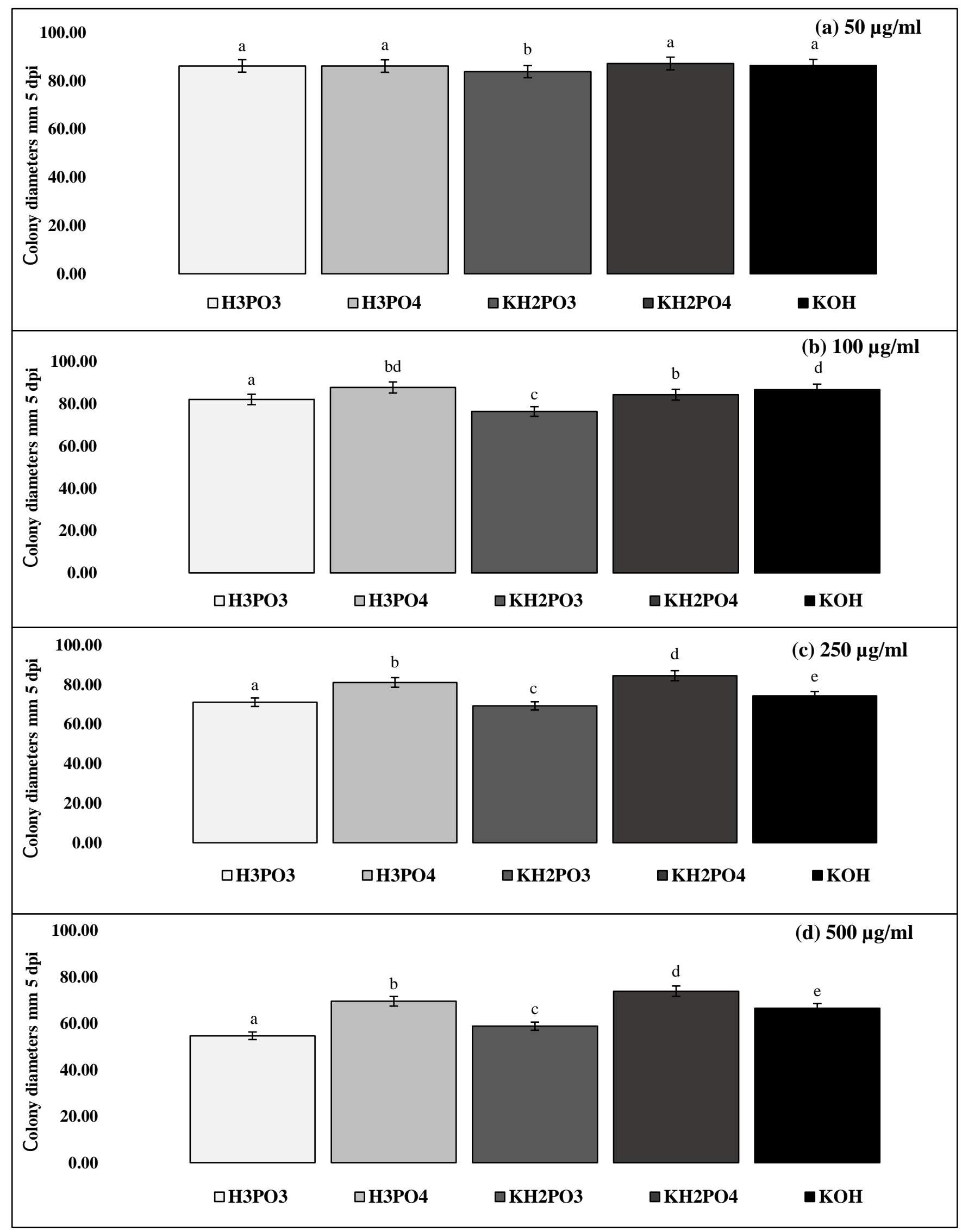

Figure 3 Effect of immersion of Microdochium nivale mycelium in solutions of phosphorous acid $\left(\mathrm{H}_{3} \mathrm{PO}_{3}\right)$, phosphoric acid $\left(\mathrm{H}_{3} \mathrm{PO}_{4}\right)$, dihydrogen potassium phosphite $\left(\mathrm{KH}_{2} \mathrm{PO}_{3}\right)$, dihydrogen potassium phosphate $\left(\mathrm{KH}_{2} \mathrm{PO}_{4}\right)$, and potassium hydroxide (KOH).

Microdochium nivale colony diameters $(\mathrm{mm}) 5$ days after transfer to unamended PDA, following immersion for 10 days in a: $50 \mu \mathrm{g} / \mathrm{ml}$; b: $100 \mu \mathrm{g} / \mathrm{ml}$; c: $250 \mu \mathrm{g} / \mathrm{ml}$; d: $500 \mu \mathrm{g} / \mathrm{ml}$ solutions of $\mathrm{H}_{3} \mathrm{PO}_{3}, \mathrm{H}_{2} \mathrm{PO}_{4}, \mathrm{KH}_{2} \mathrm{PO}_{3}, \mathrm{KH}_{2} \mathrm{PO}_{4}$ and $\mathrm{KOH}$. Data are mean values, $\mathrm{n}=6$, pooled from four $M$. nivale isolates. Bars are 95\% confidence intervals. Letters indicate significant differences between colony diameters as determined by Tukey HSD at $\mathrm{p}=0.05$. 


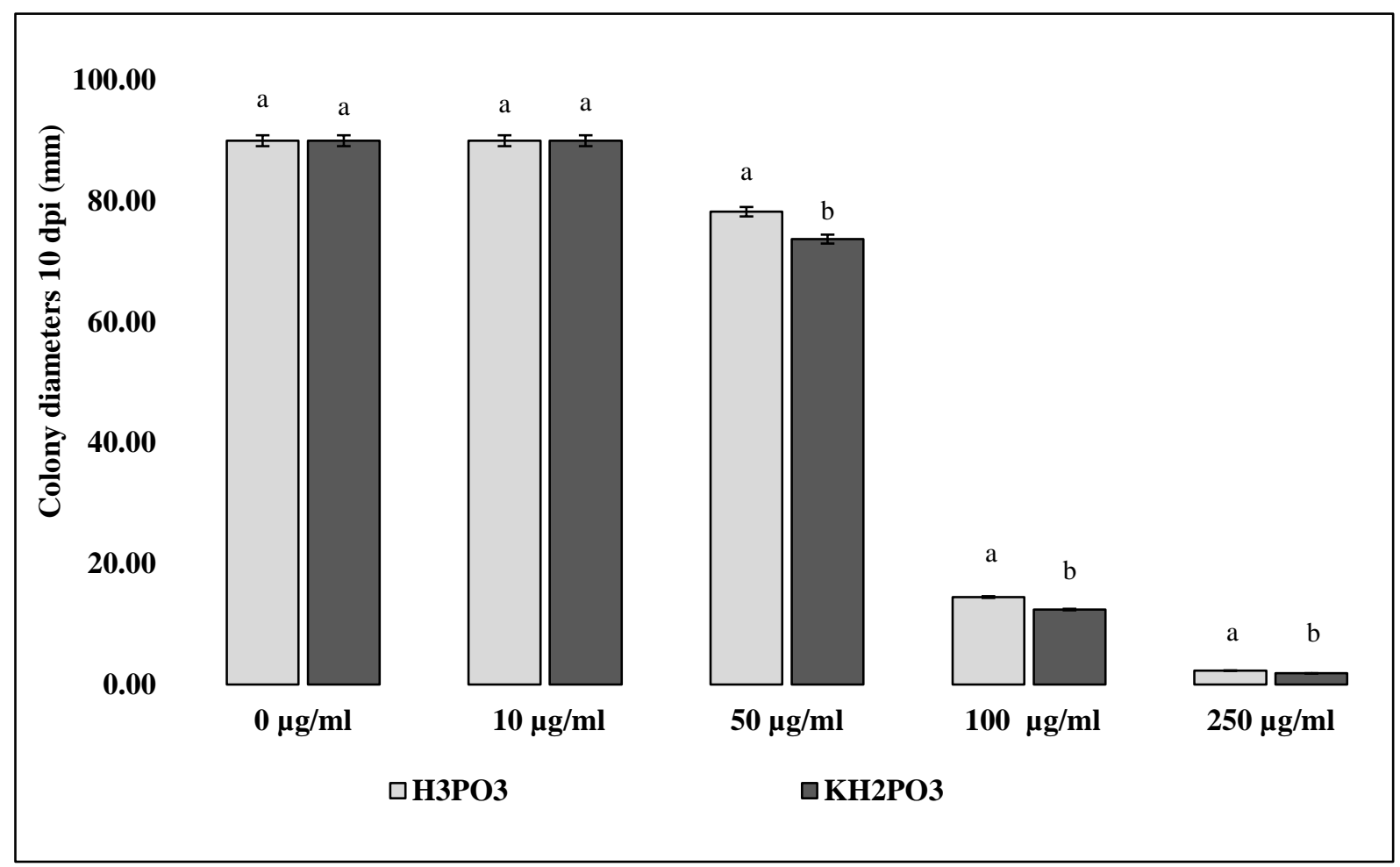

Figure 4 Radial growth of Microdochium nivale mycelium 10 days post inoculation on phosphorous acid $\left(\mathrm{H}_{3} \mathrm{PO}_{3}\right)$ and dihydrogen potassium phosphite $\left(\mathrm{KH}_{2} \mathrm{PO}_{3}\right)$ amended PDA.

Microdochium nivale colony diameters in mm, 10 days post inoculation, growing on PDA amended with 0 (control), 10,50100 and $250 \mu \mathrm{g} / \mathrm{ml}$ of $\mathrm{H}_{3} \mathrm{PO}_{3}$ and $\mathrm{KH}_{2} \mathrm{PO}_{3}$.Colony diameters were determined by measuring the radii at four points on each plate. Bars are $95 \%$ confidence intervals. Letters indicate significant differences between compounds at each amendment concentration, as determined by Tukey HSD at $\mathrm{p}=0.05$. 

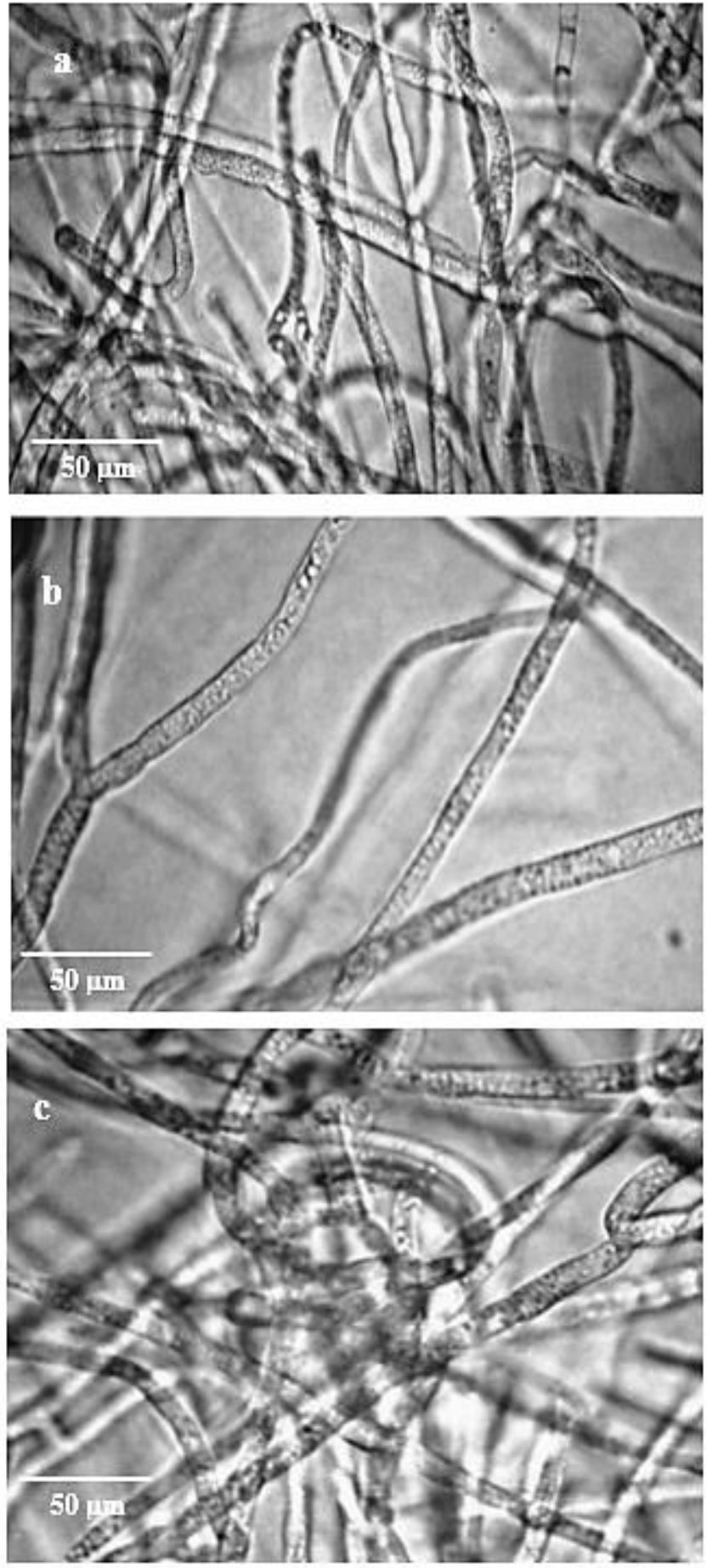
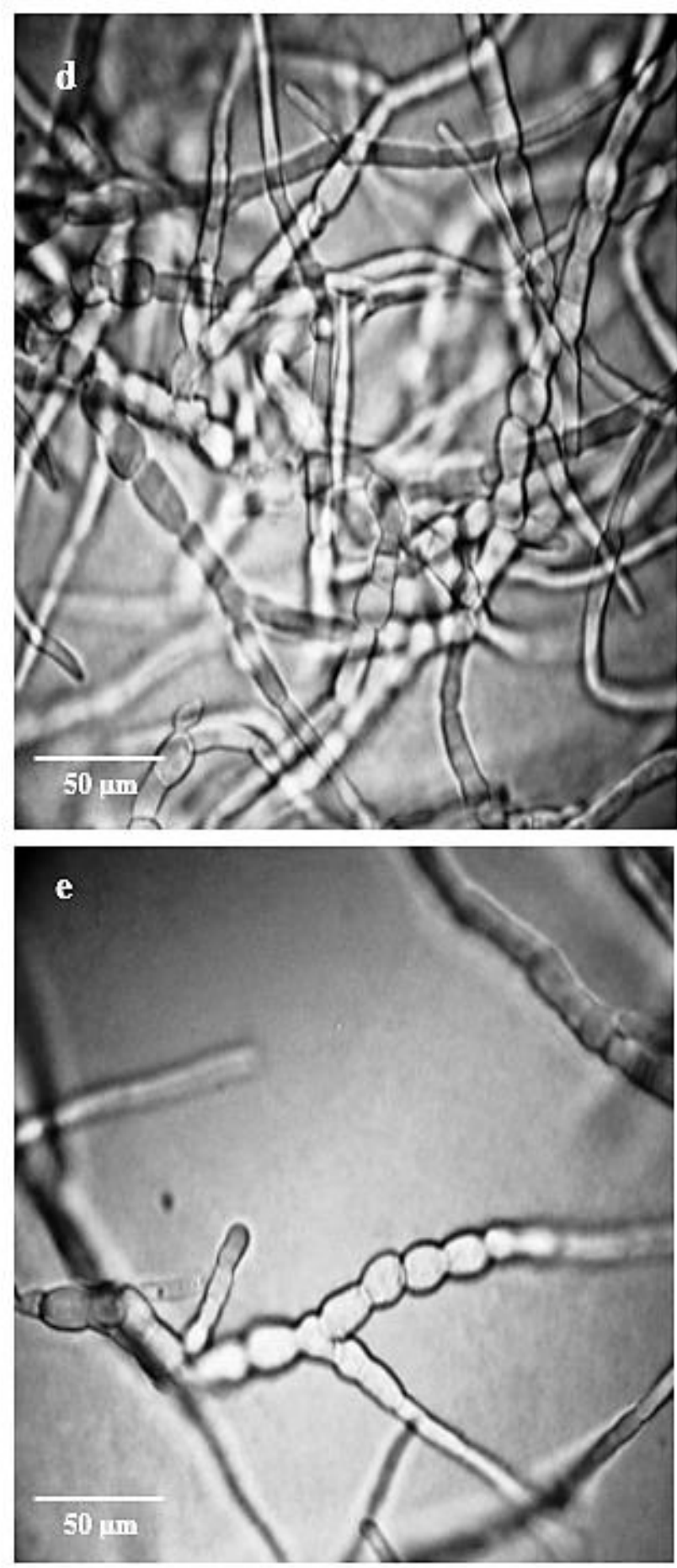

Figure 5 Brightfield micrographs of Microdochium nivale hyphal growth in amended PDA.

a: unamended control; b: phosphoric acid $\left(\mathrm{H}_{3} \mathrm{PO}_{4}\right), 100 \mu \mathrm{g} / \mathrm{ml}$; c: potassium hydroxide $(\mathrm{KOH}), 100 \mu \mathrm{g} / \mathrm{ml}$; d: phosphorous acid $\left(\mathrm{H}_{3} \mathrm{PO}_{3}\right), 75 \mu \mathrm{g} / \mathrm{ml}$; e: phosphorous acid $\left(\mathrm{H}_{3} \mathrm{PO}_{3}\right), 100 \mu \mathrm{g} / \mathrm{ml}$. 


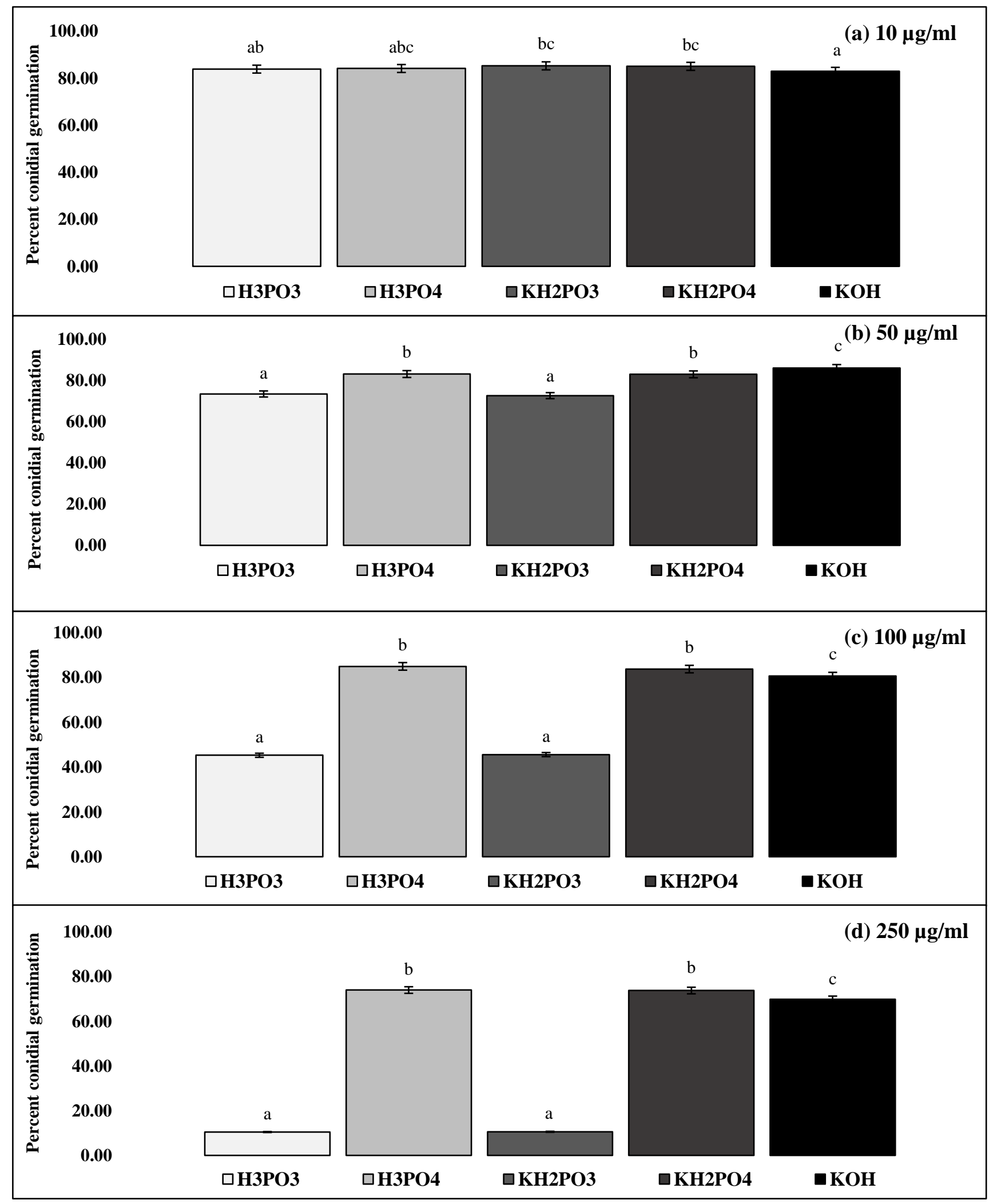

Figure 6 Effect of phosphite on germination of Microdochium nivale conidia.

Germination of $M$. nivale conidia following immersion in solutions of a: $10 \mu \mathrm{g} / \mathrm{ml} ; \mathrm{b}: 50 \mu \mathrm{g} / \mathrm{ml} ; \mathrm{c}: 100 \mu \mathrm{g} / \mathrm{ml} ; \mathrm{d}: 250 \mu \mathrm{g} / \mathrm{ml}$ $\mu \mathrm{g} / \mathrm{ml}$ concentrations of phosphorous acid $\left(\mathrm{H}_{3} \mathrm{PO}_{3}\right)$, phosphoric acid $\left(\mathrm{H}_{3} \mathrm{PO}_{4}\right)$, dihydrogen potassium phosphite $\left(\mathrm{KH}_{2} \mathrm{PO}_{3}\right)$, dihydrogen potassium phosphate $\left(\mathrm{KH}_{2} \mathrm{PO}_{4}\right)$, and potassium hydroxide $(\mathrm{KOH})$ after incubation at $18^{\circ}+/-2^{\circ} \mathrm{C}$ for $48 \mathrm{~h}$. Data were arcsine transformed prior to analysis and back-transformed for this graph. Bars are $95 \%$ confidence intervals. Letters indicate significant differences between compounds as determined by Tukey HSD at $\mathrm{p}=0.05$. 